\title{
TINJAUAN POTENSI DAYA TARIK WISATA TALUN TUJUH BIDADARI SUNGAI KUYUNG INDERAPURA SELATAN KABUPATEN PESISIR SELATAN
}

\author{
Shinta Yenisman ${ }^{1}$, Lise Asnur ${ }^{2}$ \\ Program Studi D4 Manajemen Perhotelan \\ Jurusan Pariwisata \\ Fakultas Pariwisata dan Perhotelan \\ Universitas Negeri Padang \\ Email :shintayenisman1998@gmail.com
}

\begin{abstract}
ABSTRAK
Penelitian ini dilatar belakangi oleh potensi daya tarik wisata Talun Tujuh Bidadari Sungai Kuyung Inderapura Selatan, Kabupaten Pesisir Selatan. Talun Tujuh Bidadari ini memiliki potensi yang ditinjau dari berbagai aspek salah satunya tentang keindahan alam, dan budaya yang ada. Oleh karena itu, terkait dengan potensi daya tarik wisata yang ada di Kabupaten Pesisir Selatan, penelitian ini mendeskripsikan hal-hal yang menjelaskan bagaimana potensi daya tarik wisata di Talun Tujuh Bidadari Sungai Kuyung Inderapura Selatan, Kabupaten Pesisir Selatan.

Penelitian ini merupakan penelitian deskriptif dengan data kualitatif menggunakan metode survei. Data diperoleh dari wawancara, observasi dan dokumentasi. Dalam penelitian ini melibatkan sebanyak tujuh orang yang terdiri dari satu orang Wali Nagari Inderapura Selatan, satu orang pengelola sekaligus Ketua Unit Pariwisata Inderapura Selatan, dari masyarakat setempat yang terdiri dari dua orang, dan tiga orang dari pengunjung objek wisata. Penelitian ini menggunakan teknik purposive sampling. Analisis data dilakukan dengan reduksi, penyajian data, dan penarikan kesimpulan.

Hasil penelitian ini menunjukkan bahwa daya tarik wisata ini berpotensi untuk dikembangkan dari segi atraksi wisata, aksesibilitas, fasilitas pendukung, fasilitas penunjang dan komunitas yang sangat mendukung dalam pengembangan daya tarik wisata talun tujuh bidadari ini. Pariwisata diharapkan dapat berdampak positif bagi dunia pariwisata Indonesia khususnya Kabupaten Pesisir Selatan itu sendiri, sehingga perlu perhatian dari pemerintah, masyarakat dan swasta dalam mengembangkan potensi daya tarik wisata di Pancung Soal.
\end{abstract}

\section{Kata Kunci: Talun Tujuh Bidadari, Pariwisata, Potensi Daya Tarik Wisata.}

\section{PENDAHULUAN}

Kegiatan pariwisata merupakan salah satu pemanfaatan sumber daya alam yang dapat bernilai ekonomi tinggi bagi suatu daerah yang mengelola sumber daya alam menjadi salah satu tempat wisata. Pariwisata sangat diminati oleh setiap individu, karena dengan berwisata seseorang dapat menghilangkan kejenuhan dari pekerjaan yang melelahkan. Kegiatan pariwisata mampu meningkatkan pertumbuhan ekonomi yang cepat terutama dalam penyediaan lapangan pekerjaan, peningkatan penghasilan sebagai sektor yang kompleks yang meliputi industri-industri yang bergerak di bidang jasa pariwisata. Dasar hukum pengembangan pariwisata yang sesuai dengan prinsip pengembangan adalah Undang-Undang RI No. 10 Tahun 2009, "Daya tarik wisata dijelaskan sebagai segala sesuatu yang memiliki keunikan, kemudahan, dan nilai yang berupa keanekaragaman kekayaan alam, budaya, dan hasil buatan manusia yang menjadi sasaran atau kunjungan wisatawan". Banyaknya wisata di Indonesia yang memiliki potensi untuk di kembangkan.

Inderapura adalah salah satu daerah yang berada di Kecamatan Pancung Soal Kabupaten Pesisir Selatan, yang mana di daerah tersebut banyak daya tarik wisata yang 
belum di kembangkan karena banyak wisatawan yang belum mengetahuinya. Salah satunya Talun Tujuh Bidadari yang memiliki potensi daya tarik wisata yang baru akan dikembangkan oleh masyarakat sekitar. Daya tarik wisata ini mempunyai potensi yang bagus untuk dikembangkan dari segi keindahan alam dan kejernihan airnya.

\section{Metode}

Jenis penelitian ini adalah penelitian deskriptif dengan data kualitatif dengan metode survey. Tempat penelitian dilaksanakan di Talun Tujuh Bidadari Sungai Kuyung Inderapura Selatan, Kabupaten Pesisir Selatan dan penelitian ini dilakukan pada bulan November 2020. Pengambilan data dalam penelitian ini adalah data primer dan data sekunder. Teknik pengumpulan data yang digunakan dalam penelitian ini adalah wawancara, observasi, dokumentasi. Alat yang digunakan untuk mengumpulkan data pada penelitian ini adalah peneliti sendiri dengan menggunakan alat bantuan panduan wawancara dan observasi.

Penelitian menggunakan analisis metode deskriptif kualitatif yaitu dengan mendeskripsikan secara menyeluruh data yang didapat selama proses penelitian. Menurut Sugiyono (2015:247) mengemukakan bahwa, "dalam mengelola data kualitatif dilakukan melalui tahap reduksi, penyajian data, dan penarikan kesimpulan”.

\section{HASIL PENELITIAN DAN PEMBAHASAN Hasil Penelitian}

\section{a. Gambaran Umum Talun Tujuh Bidadari}

Awal mulanya ditemukan talun tujuh bidadari oleh Kakek Pengelola saat membuka lahan tahun 1979, dan saat itu sampai 1998 diisi kebun karet dan kopi hingga di perluas menjadi 2 hektar, dan belum terpikir untuk digarap menjadi objek wisata. Hingga pada tahun 2006 terpikir untuk dijadikan objek wisata, dan tahun 2006 sampai tahun 2018 terus dikembangkan sampai sekarang ini.

Jika mendengar bidadari, nama tempat itu tidak bisa dilepaskan dari mitos atau cerita tetua setempat. Kerena namanya sendiri disematkan dari sana.Konon itu dulunya diceritakan sebagai tempat persinggahan dan pemandian tujuh bidadari. Selain air terjun (talun) yang tiga tingkat, tempat ini juga memiliki objek lain seperti, ngalau atau gua, batu tebing dan pemandangan alam yang indah.

\section{b. Temuan Khusus}

Selama melakukan penelitian di Talun Tujuh Bidadari Sungai Kuyung, peneliti telah melakukan pengumpulan data berdasarkan pada pedoman wawancara yang akan dijabarkan sebagai berikut:

1. Atraksi Wisata

Salah satu yang ingin dinikmati oleh pengunjung pada kawasan wisata yaitu adanya atraksi wisata. Atraksi wisata yang bisa dilakukan di Talun Tujuh Bidadari yaitu hiking, kemping, foto-foto, mandi-mandi, dan manjat tebing serta masih banyak lagi atraksi wisata yang bisa dinikmati seperti budaya daerah setempat. Berdasarkan hasil wawancara penelitian dapat disimpulkan bahwa atraksi wisata yang ada belum dapat menarik minat pengunjung untuk datang ke Talun Tujuh Bidadari, namun dengan adanya pemandangan alam yang masih alami contoh pepohonan yang ada di sekitar destinasi wisata Talun Tujuh Bidadari masih terawat dan terjaga kebersihannya. Selain itu masyarakat masih memanfaatkan aliran sungai sebagai tempat untuk melakukan aktifitas sehari-hari seperti mencuci dan mandi

\section{Aksesibilitas}

Akses yang harus di tempuh oleh pengunjung cukup susah apabila setelah hujan turun karna keadaan jalan yang masih berlumpur dan harus melewati anak sungai serta tebing yang curam. Saat menempuh jalan ini, pengunjung hanya bertemu jalan kerikil sepanjang 1 kilometer dan jalan setapak tanah 1,5 kilometer. Peta jalannya melalui pemukiman warga, sawah dan ladang setelah itu barulah sampai di lokasi talun tujuh bidadari.Ketika menggunakan sepeda motor akan menghabiskan wkatu sekitar 15 menit jarak tempuh dari simpang tiga Teluh (nama simpang jalan nagari setempat) dan 30 menit dari simpang jalan 
Jurnal Bosaparis: Pendidikan Kesejahteraan Keluarga

Volume 11, Nomor 1, Maret 2020

raya Padang-Bengkulu, tepatnya sebelah kiri Painan (Utara) dan kanan dari Tapan dan Silaut (Selatan).

Berdasarkan wawancara penellitian yang telah direduksi dari beberapa informan bahwa potensi daya tarik wisata Talun Tujuh Bidadari yang dilihat dari aksesibilitas menuju destinasi wisata Talun Tujuh Bidadari ini sangat mudah namun akan terganggu apabila hujan turun serta setelah hujan turun maka jalannya akan sulit untuk dijangkau karna licin dan becek. Serta juga harus ada pegangan untuk pengunjung agar merasa aman untuk menempuh perjalanan dan sangat cocok sekali bagi pengunjung yang suka berpetualang untuk melakukan hiking.

3. Fasilitas Pendukung

Fasilitas pendukung merupakan sarana dan prasarana yang di peruntukkan bagi pengunjung dalam melakukan aktifitas kehidupan keseharian seperti toilet, tempat parkir dan lain-lain. Fasilitas pendukung ini biasanya tidak hanya digunakan oleh pengunjung namun juga oleh masyarakat sekitar untuk melakukan kegiatan sehari-hari. Berdasarkan wawancara penelitian yang telah direduksi dari beberapa informan bahwa potensi daya tarik wisata Talun Tujuh Bidadari yang dilihat fasilitas pendukung yang ada di destinasi wisata Talun Tujuh Bidadari sebaiknya lebih ditingkatkan lagi karna banyak dari pengunjung yang mengeluhkan lokasi parkir jauh dari lokasi destinasi wisata Talun Tujuh Bidadari. Namun untuk musholla lebih diperhatikan keadaan musholla karna bagi pengunjung yang datang musholla disana masih seperti musholla darurat, serta untuk toilet lenih diperhatikan kebersihannya.

4. Fasilitas Penunjang

Salah satu bentuk dari fasilitas penunjang yang dapat memberikan kesenangan pengunjung dapat berupa pemandangan yang didukung dengan toko cinderamata, tempat duduk, serta cafe dengan tema alam yang akan membuat pengunjung merasa nyaman. Berdasarkan wawancara penelitian yang telah direduksi dari beberapa informan bahwa potensi daya tarik wisata Talun Tujuh Bidadari yang dilihat dari fasilitas penunjang yang ada di destinasi wisata Talun Tujuh Bidadari yang dengan diadakannya tempat duduk yang masih terbatas dan tempat bermain yang juga harus ada, karena dengan adanya tempat bermain dan toko souvenir dapat menjadi keunikan tersendiri di wisata Talun Tujuh Bidadari.

\section{Pembahasan}

Hasil penelitian merupakan gambaran tentang tinjauan potensi daya tarik wisata Talun Tujuh Bidadari Sungai Kuyung Inderapura Selatan, Kabupaten Pesisir Selatan. Dalam penelitian ini daya tarik wisata adalah keunikan dan keanekaragaman budaya yang dimiliki oleh suatu daerah yang dijadikan destinasi wisata yang dapat dikunjungi oleh pengunjung. Menurut Amerta (2019:4), daya tarik wisata harus memiliki 4 komponen dasar yang biasa disebut dengan Komponen 4A yaitu Attraction (daya tarik), Accessibilities (mudah dicapai), Amenities (fasilitas pendukung), dan Ancilarry Service (fasilitas penunjang).

Hal ini bisa dilihat dari daya tarik yang ada di Talun Tujuh Bidadari ini belum dapat menarik minat pengunjung untuk berkunjung ke lokasi Talun karna kurangnya daya tarik wisata yang dapat dinikmati oleh pengunjung. Oleh karena itu diharapkan kepada pihak pengelola dan kecamatan serta Dinas Pariwisata untuk selalu memperhatikan dan memberikan dukungan dalam pengembangan pariwisata yang ada di daerah agar dapat menarik minat pengunjung.

\section{SIMPULAN DAN SARAN Simpulan}

Dari penelitian yang telah dilakukan dapat diambil beberapa kesimpulan yaitu: Atraksi

Atraksi wisata yang dilakukan di wisata Talun Tujuh Bidadari seperti hiking, camping, manjat tebing, mandi-mandi, dan berselfie dimana potensi alamnya masih alami contoh pepohonan yang ada di sekitar Talun Tujuh Bidadari yang masih terawat dan terjaga kelestariannya.

a. Aksesibilitas 
Jurnal Bosaparis: Pendidikan Kesejahteraan Keluarga

Volume 11, Nomor 1, Maret 2020

Aksesibilitas yang ada di destinasi wisata Talun Tujuh Bidadari memiliki potensi, yang mana potensinya yakni dengan memperbaiki jalan menuju kearah talun karna keadaan jalan menuju ke talun masih tanah, namun apabila hujan turun maka jalan arah ke talun akan becek.

b. Fasilitas Pendukung

Fasilitas pendukung yang ada di wisata Talun TujuhBidadari memiliki potensi, dimana potensinya yakni dengan menambah toilet serta memisahkan antara toilet wanita dan pria serta tempat parkir yang harus lebih di perhatikan.

c. Fasilitas Penunjang

Fasilitas penunjang yang ada di wisata Talun Tujuh Bidadari memiliki potensi, yang mana potensinya yakni dengan menambah tempat duduk untuk mpengunjung sekaligus pengunjung dapat mengambil fhoto sesuai dengan posisi tempat duduk yang strategis, serta menambah tempat untuk orang berjualan karna sedikit sekali yang menjual

\section{Saran} souvenir untuk kenang-kenangan bagi pengunjung.

a. Bagi Pengelola

Disarankan untuk mempromosikan destinasi wisata Talun Tujuh Bidadari sebagai destinasi wisata unggul di Kecamatan Pancung Soal Kabupaten Pesisir Selatan, serta meningkatkan pembinaan dan penyuluhan kepada masyrakat yang terkait dan pengembangan terhadap kemajuan destinasi wisata Talun tujuh Bidadari.

b. Bagi Masyarakat Setempat

Saran bagi masyarakat untuk lebih berinisiatif dan berekreasi lebih maju dalam menciptakan lapangan pekerjaan sehinnga peluang pendapatan masyarakat yang di sekitar Talun Tujuh Bidadari.

c. Bagi Pengunjung yang berkunjung ke Talun Tujuh Bidadari.

Disarankan bagi pengunjung untuk merekomendasikan kepada orang lain agar datang berkunjung ke Talun Tujuh Bidadari dengan keindahan alam dan pemandangan yang masih asri yang memikat hati pengunjung.

d. Bagi Jurusan Pariwisata FPP UNP

Disarankan agar penelitian ini menjadi bahan untuk menambah wawasan dan ilmu pengetahuan, serta menjadi informasi yang memadai khususnya bagi pihak terkait dan menjadi bahan pembelajaran.

e. Bagi Peneliti Lain

Kepada para peneliti lain bisa dapat melanjutkan penelitian mengenai potensi destinasi wisata Talun Tujuh Bidadari, dan dapat menjadi dasar penelitian lanjutan seperti mengenai Strategi Pengembangan Atraksi Wisata di Talun Tujuh Bidadari.

\section{DAFTAR PUSTAKA}

Amerta, I Made Suniastha. 2019. Pengembangan Pariwisata Alternatif. Surabaya: Scopindo Media

Sugiyono. 2015. Metode Penelitian Kuantitatif, Kualitatif, dan R\&D, Bandung: Alfabeta

Undang-Undang Nomor 10 Tahun 2009 Tentang Kepariwisataan 